\title{
Evidence for a role of the ciliopathy protein MKS1 in cell polarity
}

\author{
M Collado-Hilly ${ }^{3}$, C Fisch ${ }^{3}$, B Desforges ${ }^{1}$, J Jerber ${ }^{1}$, L Combettes $^{3}$, C Campillo ${ }^{2}$, P Dupuis-Williams C $^{1,3,4^{*}}$ \\ From Cilia 2014 - Second International Conference \\ Paris, France. 18-21 November 2014
}

Mutations in the protein MKS1 cause severe developmental disorders such as Meckel-Gruber syndrome (MKS). Dysfunctional MKS1 caused a panel of cellular defects ranging from abortive centriolar migration to ciliary instability and defective ciliary signaling [1-3]. Most analyses converge to the conclusion that in vertebrates, the depletion of MKS1 leads to impairment of Hh and Wnt signaling pathways [4-9]. Accordingly, MKS1 has been shown to be localized at the transition zone and as such, involved in the ciliary membrane composition [6].

By combining two complementary cell models -a mammalian epithelial cell line and the unicellular Paramecium, we identified a new function of MKS1 in cell polarity.

We show that MKS1 displays a typical pattern of membrane-associated protein, being localised to exocytotic vesicles, the plasma and the ciliary membrane and to cell junctions during epithelial differentiation. Based on RNAi experiments of MKS1 which leads to impairment of ciliary sensory functions, defective vesicle transport and plasma membrane distension, we propose that MKS1 knockdown impairs interactions between actin and membranes.

We finally show how MKS1 depletion interferes with epithelial differentiation and cell organogenesis in 3D cultures.

\section{Authors' details \\ ${ }^{1}$ Genopole, ATIGE, Evry, France. ${ }^{2} U M R$ 8587, CNRS, Evry, France. ${ }^{3}$ UMR-S 757, INSERM, Orsay Cedex, France. ${ }^{4}$ ESPCI, Paris, France.}

Published: 13 July 2015

\section{References}

1. Dawe HR, Smith UM, Cullinane AR, Gerrelli D, Cox P, Badano JL, et al: The Meckel-Gruber Syndrome proteins MKS1 and meckelin interact and are required for primary cilium formation. Hum Mol Genet 2007, 16(2):173-186

'Genopole, ATIGE, Evry, France

Full list of author information is available at the end of the article
2. Bialas NJ, Inglis PN, Li C, Robinson JF, Parker JD, Healey MP, et al: Functional interactions between the ciliopathy-associated Meckel syndrome 1(MKS1) protein and two novel MKS1-related (MKSR) proteins. J Cell Sci 2009, 122(Pt 5):611-624.

3. Tammachote R, Hommerding CJ, Sinders RM, Miller CA, Czarnecki PG, Leightner $A C$, et al: Ciliary and centrosomal defects associated with mutation and depletion of the Meckel syndrome genes MKS1 and MKS3. Hum Mol Genet 2009, 18(17):3311-3323.

4. Breunig JJ, Sarkisian MR, Arellano Jl, Morozov YM, Ayoub AE, Sojitra S, et al: Primary cilia regulate hippocampal neurogenesis by mediating sonic hedgehog signaling. Proc Natl Acad Sci U S A 2008, 105(35):13127-13132.

5. Weatherbee SD, Niswander LA, Anderson KV: A mouse model for Meckel syndrome reveals Mks1 is required for ciliogenesis and Hedgehog signaling. Hum Mol Genet 2009, 18(23):4565-4575.

6. Cui C, Chatterjee B, Francis D, Yu Q, SanAgustin JT, Francis R, et al: Disruption of Mks1 localization to the mother centriole causes cilia defects and developmental malformations in Meckel-Gruber syndrome. Dis Model Mech 2011, 4(1):43-56.

7. Dowdle WE, Robinson JF, Kneist A, Sirerol-Piquer MS, Frints SG, Corbit KC, et al: Disruption of a ciliary B9 protein complex causes Meckel syndrome. Am J Hum Genet 2011, 89(1):94-110.

8. Zhao C, Malicki J: Nephrocystins and MKS proteins interact with IFT particle and facilitate transport of selected ciliary cargos. EMBO J 2011, 30(13):2532-2544.

9. Wheway G, Abdelhamed Z, Natarajan S, Toomes C, Inglehearn C, Johnson CA: Aberrant Wnt signalling and cellular over-proliferation in a novel mouse model of Meckel-Gruber syndrome. Dev Biol 2013, 377(1):55-66.

doi:10.1186/2046-2530-4-S1-P42

Cite this article as: Collado-Hilly et al:: Evidence for a role of the ciliopathy protein MKS1 in cell polarity. Cilia 2015 4(Suppl 1):P42.

\section{Submit your next manuscript to BioMed Central} and take full advantage of:

- Convenient online submission

- Thorough peer review

- No space constraints or color figure charges

- Immediate publication on acceptance

- Inclusion in PubMed, CAS, Scopus and Google Scholar

- Research which is freely available for redistribution
() Biomed Central

(c) 2015 Collado-Hilly et al. This is an Open Access article distributed under the terms of the Creative Commons Attribution License (http://creativecommons.org/licenses/by/4.0), which permits unrestricted use, distribution, and reproduction in any medium, provided the original work is properly cited. The Creative Commons Public Domain Dedication waiver (http://creativecommons.org/ publicdomain/zero/1.0/) applies to the data made available in this article, unless otherwise stated. 